\title{
The Determinants of Export Documentary Credit in Lebanon
}

\author{
Samih Antoine Azar ${ }^{1}$ \\ ${ }^{1}$ Professor, Faculty of Business Administration \& Economics, Haigazian University, Mexique Street, Kantari, Beirut, \\ Lebanon \\ Correspondence: Samih Antoine Azar, Professor, Faculty of Business Administration \& Economics, Haigazian \\ University, Mexique Street, Kantari, Beirut, Lebanon
}

Received: December 12, 2016

Accepted: January 4, 2017

Online Published: January 10, 2017

doi:10.5430/afr.v6n1p68

URL: http://dx.doi.org/10.5430/afr.v6n1p68

\begin{abstract}
The empirical literature on documentary credit is notoriously lacking. The main reason is the absence of clean statistics. Lebanon is an exception. Documentary credit can be either for import or for export purposes. This paper dwells on export documentary credit. The determinants of such credit can be classified into factors that are derived from the demand for exports, and additional unique factors. The derived factors are foreign demand, and the value of the exchange rate. The unique factors are borrowing costs and business and consumer confidence. Three types of export documentary credit have available data series: opened, utilized, and outstanding. The decision to open depends on all four factors. When the credit is utilized the collateral loans are repaid. Hence borrowing costs should not matter. The other three factors remain statistically significant. Outstanding documentary credit depends solely and surprisingly on foreign demand.
\end{abstract}

Keywords: Export documentary credit, Exports, Factors and determinants, ARDL estimation, Error-correction model, Cointegration, Lebanon

JEL Classification Codes: F14, C22.

\section{Introduction}

This paper is a sequel to another paper (Azar and Abdallah, 2015), which is entitled The Demand for Import Documentary Credit in Lebanon. Instead of the determinants of import letters of credit, also known as documentary credit, this paper studies the determinants of export documentary credit, referred to as just credit. Lebanon is characterized by the fact that precise and clean statistical series for import and export credit are available on a monthly basis. The commercial banks working in Lebanon are required by the Lebanese central bank to report the amounts of documentary credit, from which the aggregates are calculated and listed on the web page of the central bank. Elsewhere in the world documentary credit is considered as an off-balance sheet statistic that is not collected and aggregated. Because of the lack of data empirical papers on documentary credit are not only hard to find but strictly impossible to find. This applies to both import and export credit. Therefore the aforementioned paper can be considered as original in subject and in scope. This paper will continue this original and empirical research and dwells on export letters of credit.

It must be recognized that the determinants of export credit are derived from the determinants of exports per se. Hence export credit depend on the same factors as those that determine exports, with the addition of some variables that are uniquely linked to such credit. The task is therefore easier than is suggested and is apparent, because the empirical research on the performance of exports is colossal. Traditionally exports were counted as dependent on two factors: foreign demand and the depreciation of the foreign exchange rate, or some other price factor (Houthakker and Magee, 1969; Goldstein and Khan, 1985). While this specification endured many years, some new non-price explanatory variables were added to the relation (Grossman and Helpman, 1991, 1995; Jongwanich, 2010; Algieri, 2014; Verheyen, 2015). Algieri (2014) rehearses the literature on export demand. What is surprising in this survey is that many studies have assumed a unit foreign income elasticity. It is better to test for the magnitude of this elasticity and refrain from assuming it ad hoc.

The research on trade price elasticities is not just a curiosity. It provides an estimate of export and import demand elasticities, which are important parameters in checking the Marshall-Lerner condition of foreign trade. This condition states that the sum of the two price demand elasticities must be higher than +1 to ensure that a devaluation of the foreign exchange rate promotes exports, and leads to a stable foreign exchange market. In this regard 
economists were divided into two strands. The elasticity "optimists" believed that the condition applies, while the elasticity "pessimists" argued that the condition is violated. Since this paper studies export credit the export demand elasticity can only be found by assuming a relation between exports and export credit. If these two variables evolve proportionately then the demand elasticity of export is derived from the demand elasticity of export credits. However, there is no reason to believe in a proportionate relation. Moreover, data on worldly trade is not available on a monthly basis but is available on a quarterly basis. Since our data is monthly we need a monthly aggregate foreign demand variable. Our choice fell on the series available which is the US real disposable personal income. This variable is available both in monthly and quarterly frequency. That is why the empirical section begins by estimating the long run relation between the quarterly US real disposable personal income and the quarterly worldly trade volume. The Autoregressive Distributed Lag (ARDL) estimate of this relation produces an adjusted R-Square of 0.999448 , which is very close to a perfect goodness of fit. Hence it is reasonable to replace the volume of trade in the regressions by the US real disposable personal income. It must be noted that this does not mean that the two scale elasticities of exports, relative to trade and relative to disposable income, will be equal. As a matter of fact the scale elasticity of export documentary credit relative to the US disposable income is estimated consistently to be quite elevated from the value of +1 which is the value assumed in the literature for the scale elasticity.

As already noted for the relation between trade and US disposable income the econometric technique adopted for estimating a long run relation is the ARDL, and not the residual-based cointegration tests, or the Johansen procedure, and not even the Dynamic OLS (DOLS), or the Fully-Modified OLS (FMOLS), and the Canonical Cointegrating Regression (CCR). The advantages of the ARDL procedure are two: it can accommodate both stationary and non-stationary variables, and it does not impose the same lag length on all variables. This is in line with Nayaran and Narayan (2010) and Verheyen (2014) who use the same econometric procedure for export performance.

The paper is structured as follows. Section 2 presents the theoretical model. Section 3 is the empirical part. In this section, the econometric results are reported and these results are interpreted. The final section summarizes and concludes.

\section{Theoretical Model}

To repeat, the determinants of export documentary credit are a derived function of exports per se. The conventional specification of export performance is that exports depend only on two variables: foreign demand, and the dynamics of the foreign exchange rate. Exports can be taken as aggregates, and, in such a case, they depend on international trade and price factors. Exports can be bilateral, and, in such a case, they depend on bilateral foreign demand and the common foreign exchange rate. The purpose of this paper is to consider exports as aggregates, which implies that the series on documentary credit must be the aggregate of the country. As for the signs of the relations, it is agreed that foreign demand stimulates exports and the depreciation of the foreign exchange rate does the same.

Among the unique and other factors that may impact export credit we have selected two. The first one is the foreign interest rate, exemplified by the interest rate on the US dollar. Usually exporters borrow from their banks the amount of exports and repay the bank when the documentary credit materializes. Therefore a higher interest rate on the US dollar makes borrowing more expensive, curbing down the demand for export documentary credit. Another factor that is relevant is the aggregate income in the exporting country, i.e. the domestic income. Domestic income can stand for the capacity of firms, which means that the higher domestic income, the higher is its capacity and the more are exports. More exports in turn enhance export credit. So the relation is positive. Jongwanich (2010) exemplifies this relation. This transmission effect is not unique. A better domestic economic outlook leads to more local demand, and firms substitute the sale of their products from exports to local markets. This effect predicts a negative relation between economic outlook and exports, and in turn, on export documentary credit. This is even truer because the variable that proxy for domestic demand is taken to be the coincident indicator, as compiled by the central bank of Lebanon. This coincident indicator is an index of business and consumer confidence, and is available on a monthly frequency, while the Lebanese GDP is only available on a yearly basis.

In order to remove any skewness in the data, in order to stabilize the variance, and in order to be able to interpret the regression coefficients directly as elasticities, all variables are logged. It is known that the first difference of the natural logs is a rate of return.

\section{The Empirical Results}

From the previous section the variables of interest were identified. The dependent variable is export credit. The central bank of Lebanon reports three different measures: opened export credit, utilized credit, and outstanding credit. Therefore three separate models are estimated, one for each component of export credit. The independent variables 
are the coincident indicator, already mentioned, the US dollar interest rate, the value of the Euro in Lebanese pounds, and the US real personal disposable income. The first three variables, together with the 3 components of export credit, are available on the web site of the central bank of Lebanon, while the last variable is retrieved from the web page of the US Federal Reserve Bank of Saint Louis. All these variables take monthly figures. From the same Reserve Bank source worldly quarterly volume of trade and quarterly US real disposable personal income are retrieved.

First the order of integration of the different series is evaluated. See Table 1. The table lists the variable, the sample size, the Augmented Dickey-Fuller (ADF) tests on the log-levels, and the ADF tests on the first-differences of the logs. The ADF tests include a constant and a trend. The lag length is chosen according to the SIC information criterion. We shall adopt this information criterion for the rest of the paper in order to remain consistent all through. All variables are integrated of order one except the log of the coincident indicator, and the log of the Euro exchange rate. The latter has a p-value of 0.0162 . All the first-differences of the logs are stationary, i.e. integrated of order zero, except the log coincident indicator for which we already know it is integrated of order zero. In the same table are recorded, in brackets the lag length. It is known that unit root tests are sensitive to the lag length. None of the lag lengths is close to the allowed maximum by the information criterion of 15 lags, and all lag lengths are inferior to this value of 15 lags.

Table 1. Actual p-values of the Augmented Dickey-Fuller (ADF) unit root tests with a constant and a trend

\begin{tabular}{llll}
\hline & & \multicolumn{2}{l}{ ADF test on } \\
\cline { 4 - 4 } & Sample & $\log (\mathrm{X})$ & $\Delta(\log (\mathrm{X}))$ \\
\hline & & & \\
Worldly Volume of Trade & 1968Q4-2014Q2 & $0.1583[1]$ & $0.0000[0]$ \\
US Real Disposable Personal Income & 1968Q3-2016Q1 & $0.8282[0]$ & $0.0000[0]$ \\
Coincident Indicator (CI) & 1993M03-2016M04 & $0.0000[0]$ & - \\
Average Euro rate (EURO) & 1991M05-2016M04 & $0.0162[3]$ & $0.0000[1]$ \\
Dollar interest rate (IDOL) & 1995M07-2016M04 & $0.6623[3]$ & $0.0000[2]$ \\
US Real Disposable Personal Income (AD) & 1991M05-2016M04 & $0.9419[3]$ & $0.0000[2]$ \\
Opened Export Credit (Opened L/G) & 1992M07 2016M04 & $0.8294[5]$ & $0.0000[4]$ \\
Outstanding Export Credit (Outstanding L/G) & 1992M03-2016M04 & $0.8511[1]$ & $0.0000[0]$ \\
Utilized Export Credit (Utilized L/G) & 1992M07-2016M04 & $0.9467[5]$ & $0.0000[4]$ \\
\hline
\end{tabular}

Note: In brackets are the lag lengths selected according to the SIC Information Criterion.

As mentioned in the introductory section, the first step is to ascertain that global volume of trade and US real disposable personal income move in unison. Table 2 presents the estimate of the ARDL $(1,0)$ model, chosen out of 20 models evaluated. The short run elasticity, between the two variables, that can be found from the error-correction model (Panel A), is positive and relatively small (0.07233) but statistically significant (t-stat: 2.326$)$. The long run elasticity, which can be found from the cointegration regression (Panel B), is much higher at 0.4437, and is statistically highly significant (t-stat: 15.795). The time for adjustment to the long run can be obtained from the absolute value of the inverse of the coefficient on the lagged value of the cointegration residual. It is 28 quarters, or seven years. This figure is the only unsavory of the econometric results, because the diagnostics on the residuals show a well-behaved white noise pattern. The tests for higher order serial correlation and higher order conditional heteroscedasticity fail to reject the nulls of no serial correlation and no conditional heteroscedasticity. The only discrepancy is the ARCH effect at lag one. It is also unfortunate that the residuals do not follow a normal distribution as evidenced from the very low p-value of the Jarque-Bera normality test. However since the sample size is relatively large, made out of 185 observations, the Central Limit Theorem can be invoked for asymptotic normality. The general conclusion is that the US real disposable personal income varies with the volume of global trade in both the short and the long runs. It is therefore appropriate to replace foreign demand by the US real disposable personal income. 
Table 2. The relation between the log of the volume of global trade (volume) with the log of the US real disposable personal income. The selected model, after 20 models evaluated, is $\operatorname{ARDL}(1,0)$

Panel A: Error-Correction Model

\begin{tabular}{ll}
\hline$\Delta(\log ($ volume$))$ & $0.072331(2.326032)$ \\
\hline Lag of Cointegration Residual & $-0.035418(7.354082)$ \\
\hline Panel B: Cointegration regression & \\
\hline constant & $-3.458970(4.022873)$ \\
\hline Log(volume) & $0.443687(15.795377)$ \\
\hline Panel C: Residual diagnostics & P-value \\
\hline Test statistic & \\
\hline Ljung-Box Q-statistic: & 0.175 \\
Lag 1 & 0.165 \\
Lag 3 & 0.645 \\
Lag 12 & \\
Ljung-Box Q ${ }^{2}$-statistic: & 0.031 \\
Lag 1 & 0.131 \\
Lag 3 & 0.637 \\
Lag 12 & 0.000000 \\
Jarque-Bera normality test & \\
Breusch-Godfrey serial correlation LM test: & 0.1673 \\
1 lag & 0.1559 \\
3 lags & 0.4366 \\
12 lags & 0.4272 \\
Harvey Heteroscedasticity test & 0.0329 \\
ARCH(1) & 0.1312 \\
ARCH(3) & 0.4758 \\
ARCH(12) & \\
Nos: In parent & \\
\hline
\end{tabular}

Notes: In parenthesis are absolute t-statistics. The null hypothesis of the Ljung-Box Q-statistic on the residuals is no serial correlation. The null hypothesis of the Ljung-Box Q-statistic on the residuals squared, or $\mathrm{Q}^{2}$-statistic, is no ARCH effects. The null hypothesis of the Jarque-Bera normality test is normality. The null hypothesis of the Breusch-Godfrey serial correlation LM test is no serial correlation. The null hypothesis of the Harvey test is no heteroscedasticity. The null hypothesis of the ARCH test is no conditional heteroscedasticity. The actual p-values for all these diagnostic tests are reported. The sample size is from 1968.II till 2014:II with 185 observations.

The following step is to estimate the function that summarizes the determinants of export credit (Table 3). As already mentioned three different variables can be used: opened credit, utilized credit, and outstanding credit. The econometric procedure is still the same, i.e. by ARDL. The final models are selected among 14,406 models that are evaluated. We shall begin by studying the residual diagnostics before reporting the econometric estimates, because it appears that one of the three models is not satisfactory enough, rendering invalid hypothesis testing, and statistical interpretation and inference. The first model, with opened export credit as the dependent variable, produces exceptionally good diagnostics: no serial correlation, no conditional heteroscedasticity, or other forms of heteroscedasticity, and normality of residuals. The residuals of the second model, with utilized credit as the dependent variable, do not suffer from heteroscedasticity, either conditional or otherwise, and are normal residuals. The only discrepancy is the presence of higher-order serial correlation of the residuals, although the tests with 3 lags do not reveal serial correlation. This is puzzling because usually low-order anomalies exist while high-order anomalies are damped down and should disappear. Moreover it is not reasonable to conclude that there is a need for more than three lags for monthly data. 
Table 3. Actual p-values of the ARDL regressions residual diagnostics

\begin{tabular}{|c|c|c|c|}
\hline \multirow{3}{*}{ Test statistic } & \multicolumn{3}{|c|}{ Dependent variable (number of models evaluated per regression: 14,406 ) } \\
\hline & $\log ($ Opened L/C $)$ & $\log ($ Utilized L/C) & $\log ($ Outstanding L/C) \\
\hline & $\operatorname{ARDL}(2,4,0,0,0)$ & $\operatorname{ARDL}(2,0,0,0,1)$ & $\operatorname{ARDL}(2,0,0,0,0)$ \\
\hline \multicolumn{4}{|l|}{ Ljung-Box Q-statistic: } \\
\hline Lag 3 & 0.955 & 0.560 & 0.562 \\
\hline Lag 6 & 0.907 & 0.022 & 0.713 \\
\hline Lag 12 & 0.347 & 0.075 & 0.117 \\
\hline Lag 24 & 0.370 & 0.037 & 0.353 \\
\hline \multicolumn{4}{|l|}{ Ljung-Box $Q^{2}$-statistic: } \\
\hline Lag 3 & 0.702 & 0.690 & 0.000 \\
\hline Lag 6 & 0.650 & 0.860 & 0.000 \\
\hline Lag 12 & 0.520 & 0.469 & 0.000 \\
\hline Lag 24 & 0.295 & 0.085 & 0.003 \\
\hline \multicolumn{4}{|l|}{ Jarque-Bera normality } \\
\hline \multicolumn{4}{|l|}{$\begin{array}{l}\text { Breusch-Godfrey serial } \\
\text { correlation LM test: }\end{array}$} \\
\hline 3 lags & 0.7935 & 0.0839 & 0.1587 \\
\hline 6 lags & 0.6567 & 0.0027 & 0.3492 \\
\hline 12 lags & 0.2230 & 0.0317 & 0.0329 \\
\hline 24 lags & 0.4069 & 0.0346 & 0.1994 \\
\hline & 0.9277 & 0.5318 & 0.1606 \\
\hline
\end{tabular}

Notes: In parenthesis are absolute t-statistics. The null hypothesis of the Ljung-Box Q-statistic on the residuals is no serial correlation. The null hypothesis of the Ljung-Box Q-statistic on the residuals squared, or $\mathrm{Q}^{2}$-statistic, is no ARCH effects. The null hypothesis of the Jarque-Bera normality test is normality. The null hypothesis of the Breusch-Godfrey serial correlation LM test is no serial correlation. The null hypothesis of the Harvey test is no heteroscedasticity. The data is from March 1995 till April 2016, with 254 observations.

The model that turns out to be unsatisfactory is the model with the outstanding credit as the dependent variable. Although serial correlation is absent, whether low-order or high-order, the residuals of this model are characterized by severe conditional heteroscedasticity, and non-normality. This implies that this model should be estimated with due consideration of ARCH effects. And this is what will be done.

From these results on the econometric diagnostics it is now appropriate to interpret the two first ARDL regressions (Table 4), and leave the third regression to be estimated jointly with ARCH effects (Table 6). This is especially recommended because the bounds test fails to reject the null of no-cointegration for this third ARDL regression. According to the representation theorem by Engle and Granger (1987) a cointegration regression has an equivalent error-correction model. The cointegration regression reflects long run relations while the error-correction model reflects short run effects. We shall begin by the short run error-correction models (ECM) which are reproduced in Table 4. The first regression has the change in the log of opened export credit as a dependent variable (Table 4 , column 2), and is specified as an $\operatorname{ARDL}(2,4,0,0,0)$. Three variables enter insignificantly: IDOL, EURO, and the proxy for foreign demand (AD). As for the change in the log of the coincident indicator it is statistically significant together with three of its lags. In addition the first lag of the dependent variable is significant, but takes a negative value. A positive relation would be expected in order for intermediate effects to be higher than immediate effects. What is noteworthy is that the lag of the cointegration residual is very significant (t-stat: -7.524) has a negative coefficient, as expected, and implies an adjustment to the long run of 1.95 months, which is extremely rapid. The second regression has the change in the log of utilized letters of credit as dependent variable and has the specification of an ARDL $(2,0,0,0,1)$. In this ECM regression only two variables are statistically significant: the lagged value of the 
dependent variable, which has a negative coefficient unexpectedly, and the lagged cointegration residual which carries a negative coefficient as expected. The latter coefficient has a very high absolute t-statistic (7.224) and implies a speed of adjustment to the long run of 1.98 months, which is again very rapid.

Table 4. Error-Correction models, implied by the ARDL econometric procedure

\begin{tabular}{llll}
\hline \multirow{2}{*}{ Independent variable } & \multicolumn{3}{l}{ Dependent variable (number of models evaluated per regression: 14406) } \\
\cline { 2 - 4 } & $\Delta(\log ($ Opened L/C) & $\Delta(\log ($ Utilized L/C $))$ & $\Delta(\log ($ Outstanding L/C $))$ \\
\cline { 2 - 4 } & ARDL $(2,4,0,0,0)$ & $\operatorname{ARDL}(2,0,0,0,1)$ & ARDL $(2,0,0,0,0)$ \\
\hline $\begin{array}{l}\text { First lag of dependent } \\
\text { variable }\end{array}$ & $-0.237791(3.93494)$ & $-0.180203(2.844201)$ & $-0.155200(2.561044)$ \\
$\Delta(\log (\mathrm{CI}))$ & $1.086022(2.663894)$ & $0.129683(0.390810)$ & $0.071356(0.607440)$ \\
$\Delta(\log (\mathrm{CI}(-1)))$ & $1.281381(3.086556)$ & - & - \\
$\Delta(\log (\mathrm{CI}(-2)))$ & $1.444641(3.580889)$ & - & - \\
$\Delta(\log (\mathrm{CI}(-3)))$ & $1.573525(3.850889)$ & - & - \\
$\Delta(\log (\mathrm{IDOL}))$ & $-1.134016(1.247360)$ & $-1.412231(1.842263)$ & $-0.551937(2.081192)$ \\
$\Delta(\log (\mathrm{EURO}))$ & $-0.540938(0.796084)$ & $0.647776(1.119576)$ & $-0.011945(0.058486)$ \\
$\Delta(\log (\mathrm{AD}))$ & $-2.754569(1.235482)$ & $-3.380819(1.789728)$ & $-0.566120(0.822634)$ \\
$\operatorname{Lag}$ of Cointegration & & & \\
residual & $-0.511580(7.524381)$ & $-0.505499(7.223988)$ & $-0.062991(3.523943)$ \\
\hline
\end{tabular}

Notes: In parenthesis are absolute t-statistics. The first-difference operator is $\Delta$. CI stands for the coincident indicator of the central bank. IDOL stands for the rate of interest on dollar deposits. EURO stands for the Euro exchange rate relative to the Lebanese pound. AD stands for Aggregate Demand, proxied by the US real disposable personal income. The data is from March 1995 till April 2016, with 254 observations.

Table 5 reproduces the cointegration regressions implied by the ARDL specifications. With the log of opened export credit as a dependent variable, the four variables chosen in the theoretical section enter with statistically significant t-statistics, with a minimum t-statistic of 3.1338, and a maximum of 7.1230 (Table 5, column 2). All coefficients carry the expected signs. In this regard the elasticity pertaining to the coincident indicator carries a negative sign, which implies that a better economic outlook makes firms sell more domestically instead of internationally. A higher interest rate on the US dollar discourages borrowings and reduces the demand for export documentary credit. A depreciation of the Euro foreign exchange rate on the Lebanese pound incites firms to demand more export credit because it incites more exports. Finally the elasticity of the AD variable is positive, as expected, is highly significant (t-stat: 7.1230), and quite large (4.6887). This means that this variable replaces very well foreign demand. The second cointegration regression, with the log of utilized export credit as a dependent variable, produces four coefficients with the expected signs. However only three coefficients out of the four are statistically significant with the following absolute t-statistics: 5.763 (for $\log (\mathrm{IDOL})$ ), 4.780 (for $\log (\mathrm{EURO})$ ), and 7.810 (for $\log (\mathrm{AD})$ ). Again the coefficient on the AD variable is relatively large (3.933) while the other two elasticities, or coefficients, hover around one in absolute values. Finally, the third regression (Table 5, column 4), which was found not to be a cointegration regression, will not be analyzed.

Table 5. Cointegration regressions, implied by the ARDL econometric procedure

\begin{tabular}{llll}
\hline \multirow{2}{*}{$\begin{array}{l}\text { Independent variable } \\
\text { Constant }\end{array}$} & \multicolumn{4}{l}{ Dependent variable (number of models evaluated per regression: 14406) } \\
\cline { 2 - 4 } $\log ($ Opened L/C) & $\log ($ Utilized L/C) & $\log ($ Outstanding L/C) \\
\cline { 2 - 4 } $\log (\mathrm{CI})$ & $-39.148694(7.081496)$ & $-34.839771(8.053377)$ & $-45.749784(3.001898)$ \\
$\log (\mathrm{IDOL})$ & $-1.532944(3.133848)$ & $-0.638788(1.804957)$ & $-1.906636(1.468058)$ \\
$\log ($ EURO) & $-1.718448(5.229039)$ & $-1.468965(5.762626)$ & $-0.983822(1.032115)$ \\
$\log (\mathrm{AD})$ & $1.534144(4.693689)$ & $1.216264(4.780198)$ & $0.485009(0.521183)$ \\
& $4.688669(7.123024)$ & $3.933264(7.809960)$ & $6.542645(3.422726)$
\end{tabular}

Notes: In parenthesis are absolute t-statistics. CI stands for the coincident indicator of the central bank. IDOL stands for the rate of interest on dollar deposits. EURO stands for the Euro exchange rate relative to the Lebanese pound. 
AD stands for Aggregate Demand, proxied by the US real disposable personal income. The data is from March 1995 till April 2016, with 254 observations.

Table 6 presents the results of estimating the following ECM, taken from Table 5 (column 4), by non-linear least squares together with an $\mathrm{ARCH}(1)$ process for the conditional variance:

$$
\begin{gathered}
\Delta \log Y_{t}=\sum_{i} \alpha_{i} \Delta \log Z_{i t}+\beta \Delta \log Y_{t-1}+\gamma \varepsilon_{t-1}+\vartheta_{t} \\
\varepsilon_{t-1}=\log Y_{t-1}-\mu-\sum_{i} \delta_{i} \log Z_{i(t-1)} \\
\sigma_{t}^{2}=\theta_{1}+\theta_{2} \vartheta_{t-1}^{2}
\end{gathered}
$$

where $\alpha_{i}, \beta, \gamma, \mu, \delta_{i}, \theta_{1}, \theta_{2}$ are all coefficients to be estimated, and where $i=4$, representing the four independent variables $Z_{i}$. The dependent variable is $Y$ which stands for the amount of export credit outstanding. Estimating the

\begin{tabular}{|c|c|c|}
\hline \multirow[b]{2}{*}{ Independent variable } & \multicolumn{2}{|l|}{ Dependent variable } \\
\hline & $\Delta(\log ($ Outstanding $\quad \mathrm{L} / \mathrm{C}))$ & $\Delta(\log ($ Outstanding $\mathrm{L} / \mathrm{C}))$ \\
\hline First lag of dependent variable & $-0.141986(1.734532)$ & \\
\hline$\Delta(\log (\mathrm{CI}))$ & $0.039503(0.273521)$ & \\
\hline$\Delta(\log (\mathrm{IDOL}))$ & $-0.482046(1.653121)$ & \\
\hline$\Delta(\log (\mathrm{EURO}))$ & $-0.024153(0.113130)$ & \\
\hline$\Delta(\log (\mathrm{AD}))$ & $-0.589823(0.527329)$ & \\
\hline Lag of Cointegration residual & $-0.059895(1.743246)$ & $-0.059245(3.074420)$ \\
\hline \multicolumn{3}{|l|}{ Implied cointegration regression } \\
\hline Constant & $-51.21673(3.651132)$ & $41.84211(10.72912)$ \\
\hline $\log (\mathrm{CI})$ & $-1.955977(1.812363)$ & \\
\hline $\log (\mathrm{IDOL})$ & $-1.142458(1.534471)$ & \\
\hline $\log ($ EURO) & $1.033798(1.284834)$ & \\
\hline $\log (\mathrm{AD})$ & $6.732469(4.194084)$ & $5.282094(12.34162)$ \\
\hline \multicolumn{3}{|l|}{ Condition variance equation } \\
\hline Constant & $0.005097(9.185208)$ & $0.006533(10.69432)$ \\
\hline $\mathrm{ARCH}(1)$ & $0.265693(2.883590)$ & $0.269987(3.405765)$ \\
\hline Adjusted R-Square & 0.041752 & 0.033109 \\
\hline \multicolumn{3}{|l|}{ Ljung-Box Q-statistic: } \\
\hline Lag 3 & 0.966 & 0.401 \\
\hline Lag 6 & 0.671 & 0.741 \\
\hline Lag 12 & 0.181 & 0.231 \\
\hline Lag 24 & 0.292 & 0.216 \\
\hline \multicolumn{3}{|l|}{ Ljung-Box $\mathrm{Q}^{2}$-statistic: } \\
\hline Lag 3 & 0.691 & 0.333 \\
\hline Lag 6 & 0.608 & 0.451 \\
\hline Lag 12 & 0.780 & 0.013 \\
\hline Lag 24 & 0.853 & 0.148 \\
\hline Jarque-Bera normality test & 0.198893 & 0.005929 \\
\hline $\mathrm{ARCH}(6)$ test & 0.5386 & 0.3466 \\
\hline $\mathrm{ARCH}(12)$ test & 0.5928 & 0.2052 \\
\hline
\end{tabular}
above system of equations jointly makes possible hypothesis testing on more than one coefficient at the same time.

Table 6. Error-Correction regression estimated with a $\operatorname{GARCH}(1,0)$ model of the conditional variance.

Notes: In parenthesis are absolute t-statistics. The first-difference operator is $\Delta$. CI stands for the coincident indicator of the central bank. IDOL stands for the rate of interest on dollar deposits. EURO stands for the Euro exchange rate 
relative to the Lebanese pound. AD stands for Aggregate Demand, proxied by the US real disposable personal income. The null hypothesis of the Ljung-Box Q-statistic on the standardized residuals is no serial correlation. The null hypothesis of the Ljung-Box Q-statistic on the standardized residuals squared, or $\mathrm{Q}^{2}$-statistic, is no ARCH effects. The null hypothesis of the Jarque-Bera normality test is normality. The null hypothesis of the ARCH test is no ARCH effects. The actual p-values of all these tests are reported. The data is from March 1995 till April 2016, with 254 observations.

Although the diagnostics of the standardized residuals of this system of equations are without fault (Table 6, column 2 ), a Wald test is conducted on whether the four $\alpha_{i}$, the $\beta$, and the three $\delta_{i}$, except the $\delta$ coefficient of $\log (\mathrm{AD})$, are zero. The test has an actual p-value of 0.1406 , meaning that the eight coefficients are jointly zero. Table 6 (column 3) repeats the estimation of the system of equations but without the eight variables pertaining to the eight non-significant coefficients. The value of $\gamma$ is -0.05925 (t-stat: 3.0744), and implies a rather fast adjustment to the long run that takes 16.88 months, or 1.41 years. The coefficient $\delta_{4}$, pertaining to $\log (\mathrm{AD})$, is 5.2821 (t-stat: 12.342) and is as high as the estimates for the same variable in Table 5 (columns 2 and 3). This estimate is the long run elasticity relative to foreign aggregate demand. The diagnostics on the standardized residuals are in general acceptable except for some heteroscedasticity that appears with the $\mathrm{Q}^{2}$-statistic for 12 lags, but not with the $\operatorname{ARCH}(12)$ statistic. However the standardized residuals are deceptively non-normal. All in all it seems that the outstanding export credit form a long run relation with only foreign demand, but no short run relation with any other variable. The reasons for these peculiarities are not clear.

\section{Conclusion}

We identified four factors that impact export credit. Two of them are derived from the conventional factors that determine exports: foreign demand, and the depreciation of the foreign exchange rate. The other two factors are borrowing costs and the domestic economic outlook. Both these factors enter negatively, while the first two enter positively. Borrowing costs are important because usually firms pledge the export credit as a collateral to borrow in advance, and these firms repay their borrowings when the documentary credit is concluded. Business and consumer confidence, by ensuring a safe and prosperous local demand, is found to decrease foreign sales.

This paper is not just an empirical exercise. Some policy implications can be drawn. Control over foreign interest rates is crucial. One may think that the Lebanese monetary authorities do not have such control. In fact they do. These rates depend on the borrowing appetite of the Lebanese government. For example the deposit rate in US dollars averages currently $3 \%$ while interest rates are near zero, or even negative, elsewhere. All this means that a smaller budget deficit is indirectly an important factor for encouraging export credit, and exports.

The paper has also shown that a high local business confidence will discourage export credit. This implies that local firms are constrained in their capacity to produce. If local demand is high these firms prefer to sell less outside and more internally. If there is a sustained improvement in the economic outlook capacity may increase. However this requires an environment of political stability that endures. Hence this variable, while affecting negatively exports, and export credit, in the short run may in the very long run have a positive impact on capacity and on sales. This transmission channel may have indirect benefits: a better outlook means more taxes, which means a lower budget deficit and a lower demand for public borrowing.

A third factor that impacts the three types of export credit, opened, utilized and outstanding, is foreign demand. It may seem that foreign demand is exogenous. However, foreign demand may be increased by appropriate marketing decisions. Since Lebanon cannot compete by reducing product costs, because it has mainly a skilled labor force, it can compete on quality: the wine industry is an example. Finally Lebanon does not take enough advantage of the demand for Lebanese products by the Lebanese diaspora which is spread out over the world. In fact the emigrants constitute a consumer pool that is many times larger than the pool of local residents.

The last factor, the foreign exchange rate, is presently impossible to manage because the central bank has adopted a policy of an adjustable peg of this rate on the US dollar. If the US dollar depreciates relative to the euro so does the Lebanese pound. Therefore this factor is less amenable to management than other factors. On the other hand if the foreign exchange rate becomes more controllable in the future, a sustained policy of depreciation is possible because Lebanon is so small that foreign trade is not affected much if Lebanese exports increase, and hence the likelihood of a trade and currency war is remote.

This paper has dwelt on macroeconomic factors. No doubt that microeconomic factors are also important, but they are difficult to translate into parameters. Future research may unravel some of these factors. However their impact 
may not be substantial because the ARDL regression of opened export credit, for example, has a very high R-square of around $89 \%$. So there is little left to explain.

\section{References}

Algieri, B. (2014). Drivers of Export Demand: A Focus on the GIIPS Countries. The World Economy, 1454-1482. https://doi.org/10.1111/twec.12153

Azar, S. A. \& K. Abdallah. (2015). The Demand for Import Documentary Credit in Lebanon. International Business Research, 8(2), 111-120.

Engle, R. F., \& C. W. J. Granger. (1987). Co-integration and Error Correction: Representation, Estimation, and Testing. Econometrica: journal of the Econometric Society, 251-276. https://doi.org/10.2307/1913236

Goldstein, M. \& M. S. Khan, M. S. (1985). Income and Price Effects in Foreign Trade, in R. W. Jones and P. B. Kenen (eds.) Handbook of International Economics, 2, Elsevier Science: Amsterdam.

Grossman, G. \& E. Helpman. (1991). Innovation and Growth in the World Economy, MIT Press: Cambridge.

Grossman, G. \& E. Helpman, E. (1995). Technology and Trade, in G. Grossman and K. Rogoff (eds.) Handbook of International Economics, 3, Elsevier Science: Amsterdam,

Houthakker, H. S. \& S. P. Magee. (1969). Income and Price Elasticities in World Trade. Review of Economics and Statistics, 51(2), 111-125.

Jongwanich, J. (2010). Determinants of Export Performance in East and Southeast Asia. The World Economy, 20-41. https://doi.org/10.1111/j.1467-9701.2009.01184.x

Nayaran, S. \& P. K. Narayan. (2010). Estimating Import and Export Demand Elasticities for Mauritius and South Africa. Australian Economic Papers, (September, 2010), 241-252. https://doi.org/10.1111/j.1467-8454.2010.00399.x

Verheyen, F. (2014). The Stability of German Export Demand Equations - Have German Exports Suffered from the Strength of the Euro? International Economics and Economic Policy, 11, 529-548. https://doi.org/10.1007/s10368-013-0260-9

Verheyen, F. (2015). The Role of Non-Price Determinants for Export Demand. International Economics and Economic Policy, 12, 107-125. https://doi.org/10.1007/s10368-014-0281-z 